\title{
Appendektomia laparoskopowa przeprowadzona w znieczuleniu przewodowym - opis przypadku
}

\section{Laparoscopic appendectomy performed under ductal anaesthetization - a case report}

\author{
Andrzej Modrzejewski, Marcin Śledź, Dominik Koś凶 \\ Pomorski Uniwersytet Medyczny w Szczecinie, Zakład Pielęgniarstwa Chirurgicznego i Ratunkowego, ul. Żołnierska 48, 71-210 Szczecin \\ $\triangle$ dmnkks@gmail.com
}

\begin{abstract}
Introduction: Laparoscopic appendectomy is performed conventionally under general anaesthetization. It has been assumed that this type of anaesthesia with accompanying patient relaxation is the optimal way to provide sufficient operating space and appropriate analgesic effect for surgical techniques that require the creation of pneumoperitoneum. Based on the reports in the literature and the case described in this paper, it can safely be stated that the current approach to anaesthesia in laparoscopic procedures is becoming less and less justified.

Case presentation: The paper presents the case of a young woman with no internal diseases who was diagnosed with acute appendicitis and qualified for laparoscopic appendectomy. The American Society of Anaesthesiology scale was rated 1 and it was decided to perform the laparoscopy under ductal anaesthesia. Both the procedure and anaesthesia went without complications, and additionally the patient could avoid the risk of potential complications resulting from general anaesthetization and muscle relaxation.
\end{abstract}

Results: The development of surgical techniques and the increasing experience of laparoscopic surgeons make the current laparoscopic procedures much shorter than the duration of the muscle relaxants, and the analgesic effect of ductal anaesthesia turns out to be totally sufficient. In addition, the case presented shows that lack of patient relaxation does not negatively affect the course of the procedure itself.

Conclusions: Operative treatment of acute abdominal disorders by laparoscopic surgery under ductal anaesthesia is feasible and safe for patients without significant internal diseases. The case presented in this paper justifies the need for more extensive use of this method of anaesthesia during laparoscopic procedures of acute abdominal disorders, and the final value of ductal anaesthetization during surgical treatment with the laparoscopic technique should be determined on the basis of prospective studies comparing the use of both methods of anaesthesia.

Keywords: laparoscopic appendectomy; ductal anaesthetization; acute appendicitis.

\begin{abstract}
ABSTRAKT
Wstęp: Appendektomia laparoskopowa przeprowadzana jest standardowo w znieczuleniu ogólnym. Przyjęto, iż taki rodzaj znieczulenia z towarzyszącym zwiotczeniem pacjenta jest najbardziej optymalnym sposobem, aby zapewnić wystarczającą przestrzeń operacyjną oraz odpowiedni efekt przeciwbólowy dla technik operacyjnych wymagających wytworzenia odmy otrzewnowej. Na podstawie doniesień w piśmiennictwie oraz przypadku opisanego w niniejszej pracy śmiało można stwierdzić, iż dotychczasowe podejście do znieczulenia w zabiegach laparoskopowych staje się coraz mniej uzasadnione.

Omówienie przypadku: W pracy przedstawiono przypadek młodej, nieobciążonej internistycznie kobiety, u której rozpoznano ostre zapalenie wyrostka robaczkowego i którą zakwalifikowano do laparoskopowej appendektomii. Stopień ryzyka operacyjnego w skali Amerykańskiego Towarzystwa Anestezjologów (American Society of Anaesthesiology) oceniono na I i zdecydowano o przeprowadzeniu zabiegu w znieczuleniu przewodowym. Zabieg i znieczulenie przebiegały bez komplikacji, jednocześnie chora uniknęła ryzyka potencjalnych powikłań wynikających ze znieczulenia ogólnego i zwiotczenia.
\end{abstract}

Wyniki: Dzięki rozwojowi techniki operacyjnej oraz coraz większemu doświadczeniu operatorów wykonywane obecnie zabiegi laparoskopowe trwają znacznie krócej niż okres działania leków zwiotczających, a efekt przeciwbólowy znieczulenia przewodowego okazuje się zupełnie wystarczający. Ponadto omawiany przypadek chorej dowodzi, iż brak zwiotczenia w żaden sposób nie wpływa negatywnie na przebieg samego zabiegu.

Wnioski: Leczenie operacyjne ostrego schorzenia jamy brzusznej metodą laparoskopową w znieczuleniu przewodowym jest wykonalne i bezpieczne u pacjenta bez istotnych obciążeń internistycznych. Przedstawiony w pracy przypadek chorej uzasadnia potrzebę szerszego stosowania tej metody znieczulenia w trakcie laparoskopowych operacji ostrych schorzeń jamy brzusznej, a ostateczna wartość znieczulenia przewodowego podczas zabiegów techniką laparoskopową powinna zostać określona na podstawie dalszych prospektywnych badań porównujących zastosowanie obu metod znieczulenia.

Słowa kluczowe: appendektomia laparoskopowa; znieczulenie przewodowe; ostre zapalenie wyrostka robaczkowego. 


\section{WSTĘP}

Appendektomia jest jedną z najczęściej wykonywanych procedur na oddziałach chirurgicznych w ramach ostrego dyżuru. Wraz z rozwojem technik małoinwazyjnych oraz coraz lepszym wyszkoleniem chirurgów wzrosła liczba zabiegów przeprowadzanych metodą laparoskopową. Niestety małoinwazyjność zabiegu chirurgicznego pozostaje w pewnej sprzeczności z tradycyjnym zastosowaniem znieczulenia ogólnego do zabiegów laparoskopowych. Choć podejście takie nie jest poparte wynikami badań porównawczych różnych metod znieczulenia w tego typu operacjach, to utarło się, iż do przeprowadzenia zabiegu metodą laparoskopową potrzebne jest znieczulenie ogólne. Ten rodzaj znieczulenia w porównaniu z innymi metodami wiąże się z istotnie większym ryzykiem powikłań.

Celem niniejszej pracy jest wykazanie, iż znieczulenie przewodowe podczas appendektomii laparoskopowej jest wbrew powszechnie panującej opinii równie odpowiednim sposobem znieczulenia jak znieczulenie ogólne.

\section{OMÓWIENIE PRZYPADKU}

24-letnia pacjentka, która do tej pory nie chorowała, nie była leczona przewlekle i nie zażywała żadnych leków na stałe, została przyjęta na Oddział Chirurgii Ogólnej Szpitala Powiatowego z powodu narastających dolegliwości bólowych jamy brzusznej, zlokalizowanych w prawym podbrzuszu. Dolegliwości zaczęły się w dniu poprzedzającym zgłoszenie się do szpitala. Dodatkowo w dniu przyjęcia do objawów dołączyły nudności i brak apetytu.

$\mathrm{W}$ badaniu przedmiotowym $\mathrm{z}$ istotnych odchyleń stwierdzono bolesność uciskową prawego podbrzusza wraz z zaznaczonymi objawami otrzewnowymi w tej lokalizacji. W ramach diagnostyki różnicowej pacjentkę skonsultowano ginekologicznie, nie znajdując danych dla schorzenia ginekologicznego, wykonano także badanie ogólne moczu, wykluczając zapalenie dróg moczowych.

W badaniach laboratoryjnych $\mathrm{z}$ istotnych odchyleń stwierdzono leukocytozę - $13600 \mathrm{leu} / \mathrm{mm}^{3}$ oraz nieco podwyższony poziom białka C-reaktywnego - 12,81. Prawidłowe poziomy trombocytów, APTT, PT i INR pozwoliły zaplanować leczenie operacyjne w znieczuleniu przewodowym. Stopień ryzyka operacyjnego w skali Amerykańskiego Towarzystwa Anestezjologów (ASA) oceniono na I.

Rozpoznano ostre zapalenie wyrostka robaczkowego i pacjentkę zakwalifikowano do laparoskopowej appendektomii. Po przedstawieniu różnych metod znieczulenia wraz z możliwymi powikłaniami każdej z nich pacjentka wyraziła zgodę na zabieg przeprowadzany w znieczuleniu przewodowym. W premedykacji zastosowano $15 \mathrm{mg}$ Dormicum doustnie oraz Volumen $500 \mathrm{~mL}$ dożylnie. Znieczulenie wykonano za pomocą igły G27, podając $4 \mathrm{~mL}$ (20 mg) Bupivacainy Spinal Heavy w przestrzeni międzykręgowej pomiędzy L3 a L4. W ciągu całego zabiegu chirurgicznego trwającego $30 \mathrm{~min}$ dodatkowo podano Diazepam $20 \mathrm{mg}$ w 2 równych dawkach podzielonych. W trakcie trwającego znieczulenia przetoczono także $500 \mathrm{~mL}$ soli fizjologicznej oraz $500 \mathrm{~mL}$ płynu wieloelektrolitowego. Zabieg wykonano w odmie o ciśnieniu $12 \mathrm{mmHg}$, z trzech dojść: 2 troakary o średnicy $10 \mathrm{~mm}$ ustalono w okolicy pępka, jeden o średnicy $5 \mathrm{~mm}$ w przedłużeniu linii pachowej przedniej nieco poniżej pępka. Przebieg operacji nie odbiegał od innych przypadków appendektomii laparoskopowej wykonywanych w znieczuleniu ogólnym. Nie stwierdzono trudności w wytworzeniu igłą Veressa odmy otrzewnowej oraz zbyt małej przestrzeni w podbrzuszu, która utrudniałaby prowadzenie zabiegu.

Obraz śródoperacyjny oraz badanie histopatologiczne wyciętego wyrostka potwierdziły rozpoznanie ostrego ropnego zapalenia wyrostka robaczkowego. $\mathrm{W}$ trakcie przebiegu pooperacyjnego $\mathrm{w}$ leczeniu przeciwbólowym stosowano wlew tramadolu $200 \mathrm{mg}$ oraz metamizolu 2,5 g w $50 \mathrm{~mL}$ soli z przepływem $2 \mathrm{~mL} / \mathrm{h}$ w ciągu zerowej doby pooperacyjnej, osiągając wystarczający efekt.

\section{DYSKUSJA}

Od początku istnienia technik laparoskopowych nieodłącznie związane one były ze znieczuleniem ogólnym i zwiotczeniem pacjenta. Przeważał pogląd, że tylko znieczulenie ogólne pozwoli uzyskać dość przestrzeni operacyjnej oraz odpowiedni efekt przeciwbólowy dla technik związanych z wytworzeniem odmy otrzewnowej. Wraz z rozwojem techniki operacyjnej oraz nabywaniem doświadczenia przez operatorów nieraz okazuje się, że najczęściej wykonywane zabiegi metodą laparoskopową trwają znacznie krócej niż okres działania leków zwiotczających. Dodatkowo powstaje problem skutecznego leczenia przeciwbólowego po zakończeniu znieczulenia ogólnego. Podstawowymi sposobami leczenia przeciwbólowego jest stosowanie środków działających ogólnie, które podawane są zazwyczaj parenteralnie. Bardzo często uzupełnia się ich działanie śródoperacyjnie lekami miejscowo znieczulającymi o długim okresie półtrwania. Ostrzykuje się nimi miejsca wprowadzenia trokarów.

W piśmiennictwie można znaleźć doniesienia o próbach leczenia metodami laparoskopowymi pacjentów, które polegają na zastosowaniu znieczulenia przewodowego wraz z dożylnym wlewem dexmedetomidine albo fentanylu czy ketaminy, głównie jako leków znieczulających [1]. Część autorów zaleca znieczulenie zewnątrzoponowe w trakcie zabiegu oraz zewnątrzoponowy wlew fentanylu i bupiwakainy po zabiegu [2].

Okazuje się że bardzo dobry efekt przeciwbólowy przy zabiegach laparoskopowych można uzyskać, stosując wyłącznie znieczulenie przewodowe. Jednocześnie nie musi ono być uzupełnione o znieczulenie ogólne. Przedstawiony przypadek chorej operowanej w znieczuleniu podpajęczynówkowym zdecydowanie pokazuje, że oprócz doskonałego efektu przeciwbólowego chirurg może bezpiecznie przeprowadzić zabieg laparoskopowy bez zwiotczania pacjenta. Unikając konieczności intubacji, zmniejsza się jednocześnie ryzyko wystąpienia istotnych powikłań podczas znieczulenia przewodowego. 
Wydaje się, że tak dobry efekt można osiągnąć szczególnie u pacjentów szczupłych, w dobrym stanie ogólnym, wydolnych krążeniowo i oddechowo, istotnie nieobciążonych, a więc ocenianych przez anestezjologów jako ASA I lub II [3].

\section{WNIOSKI}

Przedstawiony przypadek i powodzenie w jego leczeniu pozwala sformułować następujące wnioski:

1. Leczenie operacyjne ostrego schorzenia jamy brzusznej metodą laparoskopową w znieczuleniu przewodowym jest wykonalne i bezpieczne u pacjenta bez istotnych obciążeń internistycznych.

2. Opisany przypadek zachęca wg autorów do częstszego stosowania znieczulenia przewodowego podczas operacji laparoskopowych przeprowadzanych w przypadku ostrych schorzeń jamy brzusznej.
3. Ostateczna wartość znieczulenia przewodowego w trakcie leczenia operacyjnego techniką laparoskopową ostrych schorzeń jamy brzusznej powinna zostać określona na podstawie dalszych prospektywnych badań porównujących zastosowanie obu metod znieczulenia.

\section{PIŚMIENNICTWO}

1. Jun GW, Kim MS, Yang HJ, Sung TY, Park DH, Cho CK, et al. Laparoscopic appendectomy under spinal anesthesia with dexmedetomidine infusion. Korean J Anesthesiol 2014;67(4):246-51. doi: 10.4097/kjae.2014. 67.4.246.

2. Mane RS, Patil MC, Kedareshvara KS, Sanikop CS. Combined spinal epidural anesthesia for laparoscopic appendectomy in adults: A case series. Saudi J Anaesth 2012;6(1):27-30. doi: 10.4103/1658-354X.93051.

3. van Zundert AA, Stultiens G, Jakimowicz JJ, Peek D, van der Ham WG, Korsten $\mathrm{HH}$, et al. Laparoscopic cholecystectomy under segmental thoracic spinal anaesthesia: a feasibility study. Br J Anaesth 2007;98(5):682-6. doi: $10.1093 /$ bja/aem058. 